\title{
LEAVING POLITICS: WHAT BURMESE GENERALS CAN LEARN FROM SOUTH KOREAN AND INDONESIAN EXPERIENCES
}

\author{
Zoltan Barany
}

\begin{abstract}
The Burmese generals'five-year liberalization project has allowed only modest steps towards real democracy. Which model of post-military rule transition is most instructive to Burma's opposition activists? This article argues that they should look most seriously at the Indonesian experience though, given the great power of the Burmese military, they are likely to be at the beginning of a long and arduous road toward democracy.
\end{abstract}

Keywords: military rule, democratization, South Korea, Indonesia, Burma/Myanmar

\section{INTRODUCTION}

In 2011, the Burmese generals finally responded to the deep-seated popular dissatisfaction and years of international economic and political sanctions and began a modest opening of the political system to competitive politics. Since 2013, however, many democracy activists and politicians in Burma and abroad have been concerned about what they consider the stalling of the nascent democratization process and about the reversibility of the few modest changes thus far implemented. Although national elections are scheduled for November 2015 there are questions as to whether these are going to be marred by electoral fraud or whether all sides would respect the results. Suspicions about the commitment of the generals to genuine political change are well founded.

Many observers in Burma and abroad believe that once some international political and economic sanctions were lifted and the Naypyidaw regime's international isolation had diminished, the generals' willingness in giving up power had largely evaporated. To 
date no ceasefire agreement has been signed between the government and the country's ethno-religious minorities even after six rounds of talks. ${ }^{1}$ The government has failed to safeguard, let alone to discontinue discriminatory policies against the Rohingya, an embattled Muslim minority group that Buddhist extremists have repeatedly attacked. Over 140,000 of the Rohingya Muslims were "dumped in dirty camps" since they were displaced in sectarian violence in 2011; their conditions, as United Nations (UN) special rapporteur on Burma, Yanghee Lee, recently observed, continue to be appalling.

President Thein Sein has repeatedly rejected a call by members of parliament and opposition politicians to reform the Constitution, more specifically, to change Article 436, which allows the military an effective veto over reform. ${ }^{2}$ Commander-in-Chief, Senior General Min Aung Hlaing, has maintained that "the country was not ready" for a reduced military role in the legislature. ${ }^{3}$ Many believe that the United States (U.S.) and other democracies have failed to use their significant leverage against the Burmese government, making a mistake that might well have indirectly contributed to the backsliding of Naypyidaw's human rights record.

The fundamental objectives of democratization processes are similar the world over: a competitive multiparty system, universal suffrage, free and fair elections, and so on. The specific tasks of democratizers, however, are largely dependent on the type of regime they set out to transform. Whether the point of departure is an absolute monarchy, a communist state, or a military dictatorship makes an enormous difference regarding the reforms that must be undertaken. This essay is concerned with military dictatorships, more specifically, with the most vexing issue of democratic consolidation following military rule: how to turn the army that had a hold over the state into a democratic army, one that is supportive of democratic rule and is an obedient servant of the democratic state.

Today only Lesotho and Thailand are under full-fledged military rule but there are several other countries where the armed forces are, and have been for decades, the dominant political force under the façade of electoral authoritarianism: the best examples are Egypt and Pakistan. This essay, however, is primarily intended to address democracy activists in countries that are currently undergoing a 
precarious transition away from military dictatorship, such as Fiji and, especially, Burma. On a recent visit to the latter, opposition figures repeatedly lamented to me that the generals' partial and the tentative opening of political space in 2011 was far from "irreversible."

This notion of "irreversibility" brings up the question of whether the army's withdrawal from politics is ever truly irreversible? After all, even in long-established democracies what keeps soldiers from interfering in politics and, ultimately, using their weapons against civilians are (i) their commitment to civilian rule and (ii) the state's capacity to establish a system of control mechanisms that effectively precludes the generals' political involvement. Therefore, the fundamental objectives of democratizers' vis-à-vis the military must be to cultivate officers who support democratic government and to develop the institutional conditions that prevent the military's intrusion in politics.

Generals tend to relinquish their power for one of two broad reasons. The first is when they decide to withdraw from politics because they are incompetent and unpopular rulers to be replaced by effective political force opposing them (examples: Greece, 1974; and Argentina, 1983). The second category is when military elites willingly transfer political power to civilians for one or more of the four following reasons: they (i) ran the country and, in their own minds at least, accomplished their objectives; (ii) believe that their continued participation in politics would jeopardize their social esteem and institutional prestige; (iii) experience "governance fatigue," that is, having grown weary of political responsibilities they wish to return to the barracks; and (iv) abide by their pledge to call free and fair elections or referenda and respect the results (examples: Turkey, 1983; South Korea, 1987; Chile, 1990). ${ }^{4}$ It seems doubtful that the Burmese army, the Tatmadaw, currently fits into any of these rubrics.

During the Cold War military or quasi-military regimes in East and Southeast Asia (e.g. Burma, Indonesia, the Philippines, South Korea, Taiwan, Thailand) were complemented by statesocialist polities (e.g. Cambodia, China, Laos, Vietnam). Thirdwave democratization for post-military regimes has resulted in sharply different outcomes in East and Southeast Asia. In East Asian states, such as South Korea and Taiwan, economic growth and the 
development of civil society had spurred political opening, and, in time, produced a consolidated democracy. In Southeast Asia, however, the course toward democratization has been uneven and remains very much a work in progress in Thailand, Indonesia, and the Philippines. Here the military, a traditional bastion of anti-democratic power, has reinforced authoritarian currents and continues to be the single-most important obstacle in the way of democratic consolidation.

In this article, my purpose is to outline the key developments that led to the elimination and greatly reduced political interference of the armed forces in South Korea and Indonesia, respectively, in order to draw lessons that Burmese democratizers could use. Needless to say, the two are vastly different polities: as far as civil-military relations reform is concerned, South Korea's has advanced much farther than Indonesia. Nonetheless, precisely because Burma's level of political and economic development is a long way behind Indonesia's, the latter country's experience is more immediately relevant to Burmese democratizers. Moreover, Indonesia's ethno-religious diversity - in contrast to South Korea's relative homogeneity in this regard - also makes it a more comparable case to Burma. Because for Burma's current developmental context the initial stages of democratization are the most pertinent, the time frame for this article is from the beginning of democratization until the end of Kim Dae-jung's presidency (2003) in South Korea and until the end of President Yudhoyono's first term in office in Indonesia (2009).

\section{MILITARY RULE IN SOUTH KOREA AND INDONESIA}

Historically, in both countries the armed forces were the most powerful political institutions. According to military folklore, in Indonesia soldiers were not just a part of society but they effectively created the nation while South Korean generals have considered themselves the guarantors of national survival. ${ }^{5} \mathrm{As}$ in the former military regimes of Southern Europe and Latin America, the main challenges in these Asian states have also been the extraction of the armed forces from the political realm. Politicians in South Korea and Indonesia have approached these challenges differently given the disparate political and socioeconomic settings in which they operated. 


\section{South Korea}

When South Korea became an independent state in 1948, the military was by far its best-organized social force and it remained so for about half-a-century. The armed forces were heavily influenced by Japan, whose colonial army left a deep impression on the Korean soldiers and officers, and the U.S. - the American Military Government de facto ruled the country in 1945-1948. ${ }^{6}$ President Syngman Rhee's (19481960) civilian but intensely authoritarian rule relied on the police and the armed forces. He took advantage of factional struggles within the military to consolidate his rule and to prevent the evolution of a unified power center in the army. During the social and political upheaval that followed the overthrow of Rhee's regime by a student revolution, the armed forces continued to restrain their political ambitions. The appointment of a civilian defense minister and his attempt to reduce military expenditures, the widespread corruption, and the civilian regime's alleged inability to defend the country from communist threats led to a bloodless military coup and ushered in the long rule of Park Chung-hee (1961-1979). ${ }^{7}$

Park declared martial law, dissolved the National Assembly, abolished political parties, banned political activities, and established a classic military dictatorship. The all-military Supreme Revolutionary Council for National Reconstruction took over all executive, legislative, and judicial functions of government. In 1963, following strong U.S. and public pressure, political power was transferred to the civilian sphere though the armed forces' political interference continued. ${ }^{8}$ At this point, in a concession to the Constitution that stipulated civilian control over the armed forces and forbade the election or appointment of uniformed officers as presidents, Park and his fellow officers who entered the government retired from the armed forces. Nonetheless, under the remainder of his regime the army as an 'institution' stayed out of politics but the recruitment of its retired officers for political position continued unabated. In fact, the ratio of former military personnel in the cabinet and in the legislature had increased. ${ }^{9}$ In 1964-1979, ex-officers held 118 of the 314 ministerial portfolios and occupied between 16 and 22.4 percent of the seats in the National Assembly. ${ }^{10}$ Park managed to politically control the generals by patronizing the influential Hanahoe faction and positioning its members in strategic posts within the military, by mobilizing intelligence agencies to detect 
and prevent moves by the armed forces and by co-opting retired officers into the government and thereby alleviating their political grievances. The officer corps was a staunch supporter of Park's regime and retired generals constituted the backbone of the government. Notwithstanding its civilian façade, Park's regime was, in fact, a military regime.

In late 1979, General Chun Doo-hwan organized mutiny against the old-guard generals and engineered a coup in May 1980. The change at the top resulted in few substantive policy alterations. Constitutional changes increased executive power over the other branches of government. Like Park, when Chun and his associates retired from the military, he established a new political party (the Democratic Justice Party or DPJ) and successfully controlled the armed forces. At the same time, Chun limited the retired officers' participation in government and relied almost exclusively on the Hanahoe group as the talent pool for military and government elites throughout his reign. ${ }^{11}$ For the eight years (1980-1988) of his regime Chun suffered from a legitimacy deficit owing to his forcible seizure of power and, even more so, for having crushed the Kwangju Uprising in May 1980 that took the lives of over 200 people and also created substantial anti-American sentiment among young South Koreans. Chun's entire tenure was accompanied by the unrelenting and gradually expanding and intensifying resistance of civil society which eventually forced the introduction of limited measures of political and economic liberalization.

\section{Indonesia}

Four years after declaring independence and fighting a costly guerilla war against the returning Dutch, Indonesia became a parliamentary democracy (1949-1959) and then an authoritarian state portrayed by its leading elites as a uniquely Indonesian system of 'Guided Democracy' (1959-1965). Indonesia's increasingly autocratic dictator, Sukarno, had tried to maintain a delicate balance between the country's two most powerful institutions: the Indonesian Armed Forces (Angkatan Bersenjata Republik Indonesia or ABRI) that never restricted itself to an exclusively military role, and the Indonesian Communist Party (Partai Komunis Indonesia or PKI). In 1965, Sukarno's regime was unseated by generals anxiously viewing the PKI's growing power. ${ }^{12}$ The PKI was destroyed and the military became the most influential 
political institution under Sukarno's successor, Suharto, a former ABRI lieutenant general.

The ABRI's enormous political power was legitimized by the "dual function" (dwifungsi) doctrine that stipulated that in addition to strictly military tasks, the armed forces were entitled to a direct role in political life. ${ }^{13}$ Both of these functions were facilitated by the separatist threats the country faced in Aceh, East Timor, and Papua, and ABRI's doctrine that prescribed close cooperation between military units and the civilian population. This strategy of "total people's defense," in turn, was fostered by ABRI's territorial defense structure that spread military presence all over the country. Furthermore, ABRI justified its exercise of civilian functions - territorial warfare, civil defense, involvement in the economy - by taking a leadership role of the country's "functional groups" (workers, peasants, youth, and women).$^{14}$

Under Suharto's “New Order" state (1965-1998), the armed forces was guaranteed 20 percent of the seats in the legislative bodies of all levels of government and, by the mid-1990s, 14,000 ABRI officers were employed in various administrative and economic positions. ${ }^{15}$ Nevertheless, during the last decade of his rule, Suharto had gradually reduced his reliance on the generals by forming coalitions with Islamists and technocrats, and consulting his own palace clique (including his family members). In 1993 ABRI reacted against the downgrading of its position by forcing Suharto to accept one of its own, General Try Sutrisno, as Vice President but the president retaliated by decreasing the military's presence in his cabinet. ${ }^{16}$ Moreover, Suharto deliberately created schisms along religious - and, for the first two decades of his rule, occasionally political and ethnic - lines within ABRI and periodically reshuffled large numbers of military officers in order to strengthen his authority and to prevent the emergence of consensus and of independent power centers within the military elites. ${ }^{17}$

Serious challenges to ABRI's power came from three sources: Suharto, who occasionally took positions directly at odds with the wishes of the top brass; tensions within military elites; and, particularly in the later years of Suharto's regime, opposition from the intelligence community and from the emerging civil society groups. ${ }^{18}$ Importantly, none of these factors was able to challenge ABRI's deep penetration of society, particularly rural society. 


\section{COMPARING PRAETORIAN RULE}

When contrasting the two military regimes it is worth underscoring that political intervention in Korea was exercised by individual generals and not the armed forces as an institution while in Indonesia - given ABRI's territorial organization - the entire officer corps could be said to possess some political clout. In a like vein, in Korea the spoils of the coups d'état - and of military rule, more generally - were enjoyed by those who were personally involved in the 1961 and 1979 takeovers. Those who remained in the barracks not only did not benefit from but also, in fact, were disadvantaged by military rule because public opinion did not differentiate between the two groups in the army. In Indonesia, however, larger segments of the armed forces profited materially from the military's political position and were involved in corruption.

The personalized rather than institutionalized pattern of military intervention eased the Korean armed forces' exit from politics. The regimes there were not "pure" military governments but, rather, semicivilian regimes that enjoyed the army's extensive support. At the other end of the scale was, again, Indonesia where economic growth was slower and the generals, notwithstanding some constraints on their power, managed to maintain their dominant political position.

The praetorian rule of the two states cannot be viewed in isolation from the Cold War. The Korean military's claim that it held the key to national survival was justified in a very real sense, something the population was occasionally reminded of by the brazen operations of North Korean military and intelligence. ${ }^{19}$ In Indonesia, communist insurgents and/or separatist forces did not amount to an existential threat but certainly qualified as significant security challenges that had to be defeated. The Cold War context also raises the issue of the role of foreign political actors. All three of these states were firmly allied with the West though none more so than Korea whose defense was guaranteed by the presence of the U.S. Eighth Army on Korean soil. Washington, of course, was delighted by the coup that unseated the increasingly communist-friendly Sukarno in 1965 and, along with Australia, was a steadfast backer of Suharto. There is, a profound irony here: the U.S. had been a committed supporter of both authoritarian regimes as long as it needed their co-operation in the anti-communist 
and anti-Soviet struggle. With the winding down of the Cold War, however, Washington emerged not just as a stern critic of the repressive actions of the same regimes but also as a dependable supporter of democratization efforts. ${ }^{20}$

Military rule must be viewed within the context of its time. In all both countries the armed forces had made major contributions to modernization and socio-economic development. Especially in rural areas, they played an essential role in socializing and training the population as well as improving the physical infrastructure by building roads, bridges, canals, and so on. In Korea, nearly all young men received useful technical training in the armed forces owing to the compulsory draft. It was in large part this kind of training that enabled the country's successful pursuit of labor-intensive industrialization. ${ }^{21}$ In Indonesia, the army's territorial organization fostered the close ties between soldiers and the local population and facilitated ABRI's intensive economic participation.

In both societies the public consideration of the military regimes remains polarized. Predictably, those on the left side of the political spectrum and those who actually suffered from military rule have little regard for it. Unlike many praetorian regimes in Africa, Asia, and Latin America, the two under consideration here compiled mixed records: next to the column dominated by dictatorial behavior, occasional brutality, and corruption, there is also one of achievements. When Park Chung-hee declared martial law in 1961, Korea's level of economic development was similar to Ghana's. ${ }^{22}$ Many Indonesians have maintained high esteem for the military regime for creating stability, keeping the prices of basic necessities low, promoting infrastructural development, and establishing universal access to education. ${ }^{23}$

\section{KOREA'S ROAD TO DEMOCRATIC CONSOLIDATION TRANSITION}

In 1986, Chun Doo-hwan's government, having suffered from a persistent legitimacy crisis, introduced some semi-participatory elements to the political system and agreed to a constitutional debate. The military had ample chances for political interference before democratic transition began but an influential group of moderate officers opposed getting involved. ${ }^{24}$ Democratization in Korea was 
an anticlimactic affair. Following heated deliberations regarding a constitutional amendment prior to the upcoming presidential election, Chun's hard-liner government allowed only for an indirect presidential election through an electoral college, which infuriated opposition political parties and civil society that demanded a direct popular vote. In May-June 1987, demonstrations and public protests of an unprecedented scale took place. Chun realized that he overplayed his hand, reopened negotiations with the opposition parties over a new constitution and eventually agreed to an amendment for the direct popular presidential elections. ${ }^{25}$ The December 1987 election was won by the ruling Democratic Justice Party's (DJP) candidate, Roh Tae-woo, a moderate general, who was aided by a three-way split in the opposition bloc. The armed forces, convinced by Roh that their position and perks would not be threatened, stood by during the first peaceful transfer of power in 40 years.

Though Roh was elected through a relatively free and fair electoral process, he was not the breath of fresh air many Koreans had hoped for given that he was a co-conspirator of the 1979-1980 military coup and a key partner in Chun's regime. Nonetheless, Roh Tae-woo turned out to be precisely the kind of transitional figure who is indispensable for the continued democratization of some countries. A loyal member of the army's Hanahoe faction (most of them members of the Korean Military Academy's eleventh class of 1955), Roh promoted his erstwhile classmates into the top brass thereby consolidating his authority and checking potential military opposition. In any case, the army was not threatened by Roh's moderate policies particularly because officers constituted nearly one-fifth of his cabinet and no major military reforms were introduced. Still, Roh allowed increasing legislative oversight of defense expenditures and ensured the generals' disengagement from politics during his five-year term.

Democratization progressed further when three opposition parties won enough seats in the 1988 National Assembly elections to deny the DJP a majority. ${ }^{26}$ A "grand alliance" of conservative political forces provided Roh and his government with the necessary support and stability to serve out their terms. In the meantime, North Korea became increasingly isolated in the wake of the Cold War allowing South Korean politicians and activists to focus on democratization. Prior to the 1992 presidential elections Roh made two important 
decisions that demonstrated his commitment to a smooth transfer of power: during the campaign he announced his intention to resign as the DJP's president and he introduced strict electoral laws, including a shorter campaign period and spending limits. ${ }^{27}$ By doing so, Roh increased political stability and helped to alleviate the already modest danger of what Huntington called the "praetorian problem" in democratic transitions. ${ }^{28}$

\section{Kim Young-Sam (1993-1998)}

A pro-democracy activist, Kim Young-sam was elected by a landslide in 1992 and became Korea's first truly civilian president in three decades. Although he left office five years later beleaguered by an economic crisis, charges of corruption in his cabinet, and low popularity ratings, he significantly moved forward Korea's democratization process..$^{29}$ Most importantly, Kim managed to greatly diminish the military's political influence by undertaking a major purge in the army, reforming the structure of defense administration, and replacing potentially problematic generals with those committed to democracy.

Kim started out with a broad agenda of political and economic reforms but his first target was the armed forces. He contacted top generals to discuss his reform proposals and, in the process, gained their support. He neutralized potential military opposition by relying on generals from his native Pusan and South Kyongsang region capitalizing on existing regional sentiments in the armed forces. One of Kim's main achievements was to destroy the army's traditional locus of political influence, the Hanahoe group, by removing more than one thousand high-ranking officers. ${ }^{30} \mathrm{Kim}$ reshuffled the 50 top generals and excluded all Hanahoe members from promotions and division commands. ${ }^{31}$ In 1996, he succeeded in putting on trial and getting convictions for former presidents Chun and Roh along with thirteen other generals - something that would have been unthinkable just a few years before - for large-scale corruption and their roles in the 1979 coup and the 1980 suppression of the Kwangju uprising. ${ }^{32}$ At the same time, Kim reduced the authority of the general staff and augmented that of the Ministry of Defense (MoD). The cumulative result of these measures was the dismantling of the military regime's long-established power base and the institutionalization of civilian control over the armed forces. 
During Kim's presidency the legal and organizational foundations of the defense-security establishment were thoroughly reformed. The legislature revised laws on intelligence agencies to ensure full governmental authority to formulate and implement policy. The Korean Central Intelligence Agency - renamed the Agency for National Security Planning with a civilian director - and the Military Security Command were brought under parliamentary oversight, their chain of command was altered to enhance actual government control, and they were prohibited from conducting surveillance of public and private entities and individuals, and were forced to return to their original missions..$^{33}$ The reduction in military autonomy went hand-in-hand with an expanded governmental role in the formulation of defense and security policy.

Kim's success in reforming Korean civil-military relations was facilitated by several factors. First, he enjoyed strong and wide public support. Second, moderate civil society groups that focused on institutional reform bolstered Kim's reform drive and deterred military resistance to reform. Third, the existence of a more cohesive and professional armed forces readily accepted the broadening of civilian oversight. Fourth, the low level external security threats provided Korea with a structural condition that favored democratic reforms and military withdrawal from politics. ${ }^{34}$ Finally, Kim's reform took place during a period of strong economic growth, which allowed him to authorize high procurement budgets that appeased a large segment of the military establishment.

\section{Kim Dae-jung (1998-2003)}

The election of Kim Dae-jung in 1998 marked the consolidation of democracy. Kim Dae-jung was not just the first minority-party candidate to get elected but also the country's "most famous dissident and inveterate prodemocracy fighter." ${ }^{35}$ The fact that Kim's election provoked no opposition from the armed forces despite public concerns, demonstrated just how far democratization had progressed in a decade.

Unlike his predecessor, Kim Dae-jung did not implement radical military reforms. His most important innovation in security affairs was the introduction of the so-called "sunshine policy" that placed relations with North Korea on a new foundation. This initiative explicitly 
dropped the notion of unification through absorption as the stated goal of the Republic of Korea and recognized that the route to self-security required reducing the insecurity of the other. ${ }^{36}$ Given their utmost concern with South Korea's security, the generals were understandably nervous about the implications of the "sunshine policy" but remained silent even though conservative parties vociferously opposed such a drastic shift in foreign policy. The top brass also abided by Kim Daejung's orders to offer only restrained responses to violations of South Korean waters by North Korean naval vessels.

Kim Dae-jung was intent to mollify the armed forces. Just four days after being elected, he decided to release the former military leaders prosecuted and jailed under his predecessor in a gesture aiming at national reconciliation. ${ }^{37} \mathrm{He}$ did not discriminate against members of the Hanahoe faction, he based assignments and promotion decisions on professional qualifications, and he eschewed regional favoritism. Under Kim the legislature expanded its involvement in national security issues and NGOs became somewhat more influential in public discussions of defense matters. Kim did further the cause of civilian control in 2001, by establishing the National Security Council (NSC) as a presidential advisory body to deliberate a broad range of national security issues - its members were the president, the ministers of unification, foreign affairs and trade, defense, the director of the National Intelligence Service, and the senior presidential secretary for national security and foreign affairs. ${ }^{38}$ During Roh Moo-hyun's presidency (2003-2008) the NSC ultimately became the primary defence decision-making agency and the military's role diminished to by-stander status. ${ }^{39}$

It is important to recognize that Kim Dae-jung's achievements in the field of security policy and his moderate policies toward the armed forces were made possible by Kim Young-sam, who was the pivotal Korean leader in terms of the process of establishing democratic civil military relations. It was Kim Young-sam's substantive reforms and courageous stance vis-à-vis the armed forces that enabled his successor to make magnanimous gestures toward that institution.

\section{KOREA: MILITARY IN STATE AND SOCIETY}

The Korean president has the right both to command and to administer the armed forces. In practice, these executive privileges devolve to the 
Defense Minister and his ministry. As in most advanced democracies, the Ministry of Defence (MoD) is responsible of for general policy, management, organizational matters, and public diplomacy regarding defense-security issues. All uniformed personnel are subordinated to the minister. The Joint Chiefs of Staff deals with military practice and the implementation of policy. In case of natural disasters local or national administrators can ask the military for assistance. In national emergencies, the president and the parliament must agree before the former can declare a national emergency and ask the defense minister to mobilize the armed forces.

Most defense ministers have been retired generals. Although the number of retired officers in government positions has declined, the security sector continues to serve as a major source for the recruitment of personnel for senior political and bureaucratic positions. Given their top-notch education and training and the unique skill-set erstwhile officers bring to the job market, and the crucial importance of security in Korean politics, this issue should be seen as a pragmatic use of human resources not as a heritage of authoritarianism. Importantly, Korean law prohibits the employment of former officers by defense industries for five years after retirement.

Since the late 1980s, the Korea's legislative branch has come a long way as an independent and influential political institution. The National Assembly is active in military-security affairs, both in terms of monitoring the armed forces and in terms of influencing national security policy formulation and implementation. The number of parliamentary deputies with military backgrounds has been decreasing. In 2009 there were two retired four-star generals on the parliamentary Defense Committee that participates in the budget process - committee members examine and, if necessary, alter the budget proposal - which culminates in a parliamentary vote. ${ }^{40}$

Although there may be some corruption inside the military - procurement issues are often hard to scrutinize for politicians or the National Assembly - there has been no evidence of any serious misappropriation of funds much less a hint of systematic fraud. The MoD has an experienced auditing department and the services maintain their own prosecutorial offices. The rare occurrence of corruption is partly explained by the prohibition on the army to operate enterprises 
or own business assets. Another reason is that Korean military professionals are reasonably well paid allowing them to maintain middle-class lifestyles. ${ }^{41}$ Lifetime pension benefits and job security make the military an attractive career choice, especially during difficult economic times.

Civil society played a critical role in Korea's democratic transition and since then NGOs and mass media organizations have become even more engaged in national security affairs, especially regarding unification policy and the defense budget. ${ }^{42}$ Still, public discourse on security issues could benefit for more and higher quality debate. There are few independent institutes for defense and foreign policy. Recently universities began to offer courses on military-security affairs but relatively few students have signed up for them.

\section{INDONESIA: A PLEASANT SURPRISE}

In 1997, when the Asian economic crisis began, Suharto was 76, isolated from everyday politics, and mostly interested in taking care of his inner circle. The widespread corruption of his government unleashed massive anti-Suharto demonstrations in February 1998 that turned into violent riots claiming over 1,000 lives in Jakarta alone and causing much property damage. Following protracted, mostly back-room negotiations with politicians and military leaders, Suharto resigned in May 1998 and was succeeded by his protégé and vice president B. J. Habibie. Indonesia held its first free elections after more than forty years in June 1999 and, in October 1999 the new legislature - the People's Consultative Assembly - elected a civilian president, Abdurrahman Wahid.

The military was an important participant in the negotiations that led to the transitions from Suharto to Habibie and then from Habibie to Wahid. ${ }^{43}$ The intense power struggle within the army that preceded Suharto's resignation was won by General Wiranto, who managed to obtain the backing of the country's largest Muslim organization. ${ }^{44}$ Wiranto's victory was sealed when he garnered the support of the incoming President Habibie, both for his leadership of the armed forces and for his sacking of Lieutenant-General Prabowo Subianto, Suharto's son-in-law and, as head of the Army Strategic Reserve command, Wiranto's chief rival. ${ }^{45}$ 
The evolution of post-Suharto military politics can be easily traced through the tenures of Indonesia's four post-Suharto presidents. They heavily depended on their personal relationships with leading generals and left the task of reforming the armed forces to them. Some observers condemn Indonesia's military reform for the minimal civilian participation in it. ${ }^{46}$ One can also argue, however, that staying out of the nitty-gritty of defence reform was a wise decision: by not forcing reforms on the military but letting its leaders formulate and implement them, the armed forces automatically acquired "ownership" of these reforms and was more likely to respect them. Even so, the process of military reform, as Marcus Mietzner argued, has been anything but a linear development as it reflected the fluctuations of the political reform process at large. ${ }^{47}$

\section{B. J. Habibie (1998-1999) and the ABRI/TNI}

Although Habibie's government struggled with the economy, the independence movement in Indonesia's province of East Timor, and numerous other social and political problems, during its seventeenmonth term Indonesian civil-military relations had changed considerably. Commander-in-Chief Wiranto, who also served as Minister of Defense and Security, quickly set to reform the armed forces. Habibie's close relationship with Wiranto and other military leaders - who decided to depoliticize the military and to redefine its role - eased ABRI's acceptance of the reforms.

Perhaps most importantly, the dwifungsi doctrine was jettisoned in favor of the "New Paradigm" that signified the separation of the armed forces and the police, stopped the practice of promoting activeduty military officers to non-military jobs, and generally reduced ABRI's influence in politics. The number of parliamentary seats assigned to the armed forces was cut from 75 to 38 , the generals apologized for past human rights abuses, and quite a few of the most notorious officers were dismissed. The military leadership declared ABRI's political neutrality as well as its withdrawal from Golkar, the Party of Functional Groups - formed in 1964 with the backing of army generals to counter the increasing influence of the Communists - de facto ruling party under Suharto and Habibie. Another important measure was the separation of the National Police from the armed forces. The change of the military's name to the Tentera Nasional 
Indonesia or TNI (Armed Forces of Indonesia) in April 1999 was a symbolic expression of the reforms it was undergoing.

When he entered office, Habibie declared that sovereignty for East Timor was out of the question though he did not take expanded autonomy off the table. Nonetheless, in January 1999 he detonated a political bomb by agreeing to a referendum to decide between autonomy and independence to be held in East Timor. Not surprisingly, this decision made Habibie very unpopular in the military that was heavily invested in the province. Four out of five of the 98 percent East Timorese who participated in the referendum favored independence and, after a great deal of bloodshed and brutality TNI units and paramilitary troops withdrew from the province..$^{48}$

\section{Civil-Military Relations under Abdurrahman Wahid (1999-2001)}

Abdurrahman Wahid's twenty-month term was marked by an erratic style of governance, a growing perception of incompetence, corruption scandals, and controversies. He was removed from office by a Special Session of the People's Consultative Assembly in July 2001 after months of demonstrations and political instability. The fundamental reason for Wahid's downfall, however, was that he alienated those who brought him to power, among them the army leadership.

As in other policy areas, Wahid's approach to the military was unpredictable and impulsive. Soon after entering office he made several decisions that appeared to further weaken TNI's political position. He selected a civilian defence minister and appointed generals known for their reformist thinking to senior military posts. Moreover, Wahid enthusiastically supported the prosecution of TNI officers for their alleged human rights violations. In October 1999, Wahid appointed Wiranto as Coordinating Minister for Security and Political Security Affairs, an important position that nonetheless removed him from TNI's chain of command. A few months later, Wahid sacked Wiranto from his ministership and transferred him along with 74 other commanders and staff officers. Wahid justified these actions by the on-going investigations of the army's human rights abuses in East Timor but, more likely, he wanted to "break the myth of army power" by destabilizing the top brass. ${ }^{49}$ 
The measure that proved to be most damaging for Wahid's political longevity - and that also contributed to Thaksin's undoing - was the one armies everywhere find most objectionable: repeated interference with their promotion processes. To be sure, Wahid's meddling in the TNI's internal affairs mostly aimed to advance the career of "reformist" generals but the end result was the same: he lost the top brass' support. At the end of the day, no substantial progress was made in the armed forces' democratization under Wahid. In fact, civil-military relations took a step backward during his term because his thoughtless policies created an opportunity for TNI to reclaim its political influence..$^{50}$

\section{Megawati Sukarnoputri (2001-2004) and Her Generals}

Megawati, Sukarno's daughter, was brought to power as an antidote to Wahid's mercurial rule and enjoyed solid TNI backing. She was heavily indebted to the armed forces and, in return, she became their reliable friend in the Presidential Palace. Several retired officers - many of them reform skeptics - received key positions in Megawati's administration. Arguably the most important appointment Megawati made, however, was of Susilo Bambang Yudhoyono, a retired lieutenant general from TNI's reformist wing, who served as Coordinating Minister for Security and Political Affairs and was responsible for ensuring domestic stability and civilian control over the military.

'SBY', as he is widely known in Indonesia, oversaw the search for and arrest of the perpetrators of the October 2002 Bali bombing and earned a reputation at home and abroad as one of the few Indonesian politicians serious about fighting international terrorism. Nonetheless, SBY was measured in his approach to the separatist movement in Aceh and was one of the few cabinet members who cautioned against a full-blown war there. SBY also succeeded in convincing Megawati to declare martial law there in 2003. Overall, his term as Coordinating Minister was relatively uneventful but it allowed him to burnish his public image as a calm, polite, and charismatic figure. Yudhoyono's growing popularity and his alienation from conservative generals had resulted in his increasing marginalization within the cabinet by Megawati who, for good reasons, began to see in him an emerging rival. 
Megawati reduced the authority of the Ministry of Defense as the executive's primary institutional link to the military and depended more on personal connections to top generals. The result of this practice, in combination with other political and institutional concessions to TNI, was sharply diminishing state oversight of the armed forces. ${ }^{51}$ In sum, Megawati's years in power were synonymous with rising military autonomy. At the same time, it is important to note that the two major defense-related laws (Law No. 3 of 2002 on State Defense and Law No. 34 of 2004 on the Indonesian Defense Forces) were approved by the legislature under her tenure.

\section{Susilo Bambang Yudhoyono (2004-2014)}

Long before Suharto's exit from the political scene, General Yudhoyono - who graduated first in his class of the military academy in 1973 - already advocated a diminishing political role for the armed forces. Though a former general, his election in no way signified a return to praetorianism because SBY was always considered as an outsider in ABRI: he was never seen as a great field commander and he was an intellectual and an accomplished musician. SBY married the daughter of Sarwo Edhie Wibowo, a general who, as the commander of the army's special forces, was instrumental in the destruction of the PKI. ${ }^{52}$ Not being liked by the top brass was probably an electoral asset for the new president but once he entered office, his outsider status turned into a liability in his dealings with the army. Some of the generals SBY put in place were his academy classmates and from his circle of confidants but several were selected owing to their high professionalism and reformist outlook. Nevertheless, partly because of his weak position in the military, no serious reforms have been implemented during his tenure and both the MoD and the TNI have been largely left to reform themselves.

Under Yudhoyono the legislature has become more assertive though its all-civilian Armed Forces Committee - known as "Commission One," it also covers foreign policy and communications - does not have full oversight of the budget. Then again, even the minister of defense and the TNI commander themselves lack complete information about budget implementation not to mention TNI's many business interests. A number of non-governmental organizations - such as the Centre for Strategic and International Studies (CSIS) 
and KontraS - and government think-tanks (e.g. Lemhannas) have emerged that have generated public discussion of defense-security affairs and have kept a critical eye on the defense establishment. Nonetheless, the legislature does not, as a general rule, take advantage of the considerable defense expertise located in these institutions by consulting their staff.

SBY astutely picked Juwono Sudarsono as his defense minister. A political scientist who held the defense portfolio - the first civilian in fifty years to do so - in Wahid's cabinet in 1999-2000, Sudarsono's service as defence minister spanned SBY's first term (2004-2009). By this time, civilian control over the TNI had solidified and the army's privileges have been reduced: unelected military officers could no longer hold parliamentary seats, ambassadorships were closed to active armed forces personnel, and military courts were subordinated to the Supreme Court. During Sudarsono's term, TNI as an institution became a supporter of democratization and market reform, particularly on the village, local, district, and provincial levels. According to Sudarsono, his most important achievement as defence minister was successfully convincing young officers from all service branches to prepare themselves for civilian life by acquiring skills in management, finance, law, etc. ${ }^{53}$

SBY succeeded in improving soldiers' conditions, procuring some big-ticket weapons, and reducing factionalism within the top brass (by, among other things, not meddling in high-level promotions). Moreover, military affairs, shrouded in much secrecy under Megawati's rule, have become far more transparent under SBY's presidency. ${ }^{54} \mathrm{He}$ was reelected by over 60 percent of the popular vote in 2009. In his second term, his priority has been to develop an indigenous defence industry and thereby lower procurement costs in the long-term.

\section{REMAINING SHORTCOMINGS}

Although much has been achieved in democratizing Indonesian civilmilitary relations, several problem areas remain. The head of the TNI report directly to the president not to the minister of defense. The MoD is still primarily staffed by officers (especially army officers) and the top brass retains a dominant role in the formulation of national security 
policy. Furthermore, members of the armed forces have not been held accountable for their past human rights abuses.

Perhaps the biggest problem is the continued involvement of TNI in the national economy; partly as a result, its political influence in villages, towns, and districts endures. Early in his fist term SBY promised to eliminate or at least drastically scale down the armed forces' economic involvement and in October 2004 a law passed by the legislature required TNI businesses to cease operations by 2009 . In fact, only modest progress was made. Faced with the impending deadline, in October 2009, a presidential decree followed by a Ministry of Defense directive required only a partial restructuring of military cooperatives and foundations that hold most of the armed forces' investments. ${ }^{55}$ These basic facts, however, hide a more complex truth.

In 2004-2009, Indonesia's defense budget averaged between US $\$ 3.5$ to 4.2 billion ( 0.68 percent of the GDP and 4.5 percent of the annual budget), notwithstanding its ongoing security challenges from separatist movements. For the sake of comparison: Indonesia is the world's largest archipelagic state whose landmass of over 740,000 square miles spreads over nearly 14,000 islands. In the past several years, Singapore, a 274 square-mile city-state with a population of four million, spent nearly twice as much on defense than Indonesia. ${ }^{56}$ For five years Sudarsono lobbied for substantially increased defense expenditures but in the end he realized that the TNI had to yield to social programs, poverty alleviation, education (that took 75 percent of the state budget), and infrastructural development..$^{57}$

Instability - political, economic, and social - was the most important attribute of the context in which Indonesia began its postSuharto transition. It must be acknowledged, then, that in order to ensure that the process of transition would not be reversed, concessions had to be made to the armed forces, traditionally the country's most important political actor. Keeping TNI's budget extremely low and halting their economic activities would have been tantamount to taking away the soldiers' livelihood. The TNI has already agreed to a significantly reduced political role and the erosion of many of its privileges. Its generals would have been hard pressed to tolerate the cessation of their business interests without some sort of a protest or uprising that Indonesia's fragile democracy may not have survived. 
The military appears to be satisfied with the current political situation but the peace between civilians and soldiers is predicated on the latter's continued rent-seeking activity, albeit on a much smaller scale. ${ }^{58}$ The appropriate time to force the armed forces out of the economy will come when the defense budget will be sufficient to maintaining TNI without outside revenue sources.

All in all, for most expert observers, Indonesia's post-Suharto development has been a pleasant surprise. ${ }^{59}$ The country has not disintegrated despite secessionist challenges; inter-ethnic relations particularly the occasionally tense nexus of the Indonesian majority with the small but financially powerful ethnic Chinese minority are under control; and the Muslim majority, by and large, has not been radicalized. Furthermore, even though their political role has diminished beyond most expectations, the armed forces have attempted no coup and, according to one of the top observers of Indonesian affairs, the possibility of a military takeover in the foreseeable future approaches zero as long as the current civilian polity remains stable. ${ }^{60}$

\section{CONCLUSION}

South Korea and Indonesia have undergone very different democratization processes. Unlike the praetorian states and their successors in Southern Europe and Latin America, these two military regimes have had to contend with serious security challenges that affected their militaries' position, social esteem, and the conditions of their withdrawal from politics. The important distinction between the external threats South Korea has had to contend with and the internal threats secessionist movements pose to Indonesia supports Michael Desch's argument that settings in which internal threats are combined with the absence of external ones undermine civilian control of the armed forces. ${ }^{61}$

Given the existential threat posed to it, the South Korean state had to build an economy in order to defend the country. Economic development, in time, fostered the formation of a vibrant civil society that, in turn, demanded democratization. Importantly, economics or, more precisely, the 1997 financial crisis, had a major political impact in both states but especially in Indonesia where it was the spark that ignited the democratization process. The two cases here lend support 
to the contention of modernization theory that the higher the level of socioeconomic development the better the chances of successful democratization. ${ }^{62}$

South Korea enjoyed a relatively neat and straight path to democratic consolidation without major setbacks and upheavals. In contrast, the process in Indonesia proceeded in fits and starts. This point is well illustrated by looking at the records of individual leaders that, in turn, underscores my more general argument about the decisive role they often play in the destiny of their countries. The pivotal leaders, those whose occasionally courageous actions really turned the tides, in South Korea and Indonesia are Kim Young-sam and Habibie. They were the first leaders after democratization began and were able to exploit the opportunity that opened as the military was losing ground. The example of Habibie, in particular, demonstrates that caretaker executives can be extremely effective transitional leaders. The major achievement Yudhoyono was to return his country onto the track of diminishing military influence after the setbacks suffered under his predecessors.

The main task of democratizers was to get the armed forces out of politics - even if they succeeded only partially in Indonesia. The kind of leverage the top brass enjoyed as they returned to the barracks was an important predictor of the way they were treated by the incoming civilian government. The South Korean transition to democracy is similar to the Chilean experience as far as the generals' gradual loss of privileges and the relatively smooth transfer of power is concerned. At the same time, South Korean generals had less leverage, owing to the Chun government's loss of legitimacy than their Chilean colleagues. The political position of Indonesian soldiers was more akin to the South Korean model: as participants in the negotiations leading to the transition they had enjoyed relatively high leverage and then gradually lost some of their political power - but not nearly as much as their counterparts in South Korea.

How committed to democratic rule are the generals of these three states? Only in the South Korean case could one answer with a confident affirmative; in all likelihood, Indonesian officers have gradually become more respectful of democratic values in the past decade but at this point the strength of their commitment is certainly 
debatable. This essay also illustrates the importance of careful sequencing of military reforms. Specific contexts determine what measures are feasible in the initial transition process without provoking the ire of military elites and when is it more advisable to hold off until more stability is achieved. In settings where the government is flush with money - such as Korea under Kim Young-sam - the chance to, in effect, purchase the armed forces' acquiescence by allowing them to procure new weapons and equipment - "Give them toys," is how Samuel Huntington referred to this tactic ${ }^{63}$ - should be utilized. Interfering with the promotion practices of a yet-unreformed military establishment, as Wahid had done, usually means asking for trouble. At the same time, excessively appeasing the generals for their political support can be counterproductive and, as Megawati's term nicely illustrates, can easily halt the process of the military's democratization.

\section{THE HARD ROAD FOR BURMA}

The predicament of Burmese democracy activists is far more difficult than what their colleagues faced in Indonesia, let alone South Korea. The Burmese military, the Tatmadaw, has been in power for longer (since 1962), its domination of politics and public life has been far more overpowering, and its penetration of the national economy and control of society has been far deeper than in any of the three cases discussed in this essay. Corruption is also far more pervasive in Burma and it permeates most political, societal, and commercial exchanges on every level. ${ }^{64}$ The 1988 and 2007 anti-regime uprisings revealed that the opposition - owing in part to the military government's decades-long brutal suppression of dissident activity - was divided and unable to extract major concessions from the regime. Moreover, for decades the generals virtually isolated the country from the outside world making it unusually challenging for foreign governments, non-governmental organizations (NGOs) and companies to provide assistance.

Since 2011, the junta has introduced some limited political and economic reforms and, according to its supporters at least, is "publicly committed to building a 'modern developed democratic nation'." ${ }_{65}$ Nevertheless, democracy activists are correct to argue that these changes are easily reversible and reflect the generals' interest in the suspension of foreign economic sanctions and escaping international isolation rather than any enthusiasm for democratization. ${ }^{66}$ The only 
realistic course open to democratizers Burma is to unite disparate opposition groups, forge a substantive alliance with marginalized ethno-religious minorities, and patiently but steadily pressure the generals toward further reforms and liberalization until entirely free and fair elections will decide their political destiny.

Indonesia, with its admittedly imperfect outcome, is the example that pragmatic Burmese democracy activists should keep in mind and aspire to emulate. It is sobering to remember that even in Indonesia the threat of democratic reversal was very real during the 2014 electoral campaign, sixteen years after the reform process began. ${ }^{67}$ The situation in Burma is in virtually every aspect - in terms of economic and sociopolitical development, international engagement, and the intensiveness and length of military rule - much more challenging than it was in Indonesia and realistic Burmese democracy activists ought to be prepared for a lengthy campaign. ${ }^{68}$ In sum, considering Burma's post-independence history, the Tatmadaw's enduring power, and the weaknesses of its democratic opposition, there are ample reasons to be pessimistic about the generals' withdrawal from politics in the foreseeable future.

\section{NOTES}

1 C. S. Kuppuswamy, "Myanmar: Nationwide Ceasefire Agreement and War with Kachins," Eurasia Review, 24 January 2015; and May Wong, "Myanmar Peace Process in Rebel Hands," Channel News Asia, 19 January 2015.

2 "President Rejects Constitutional Reform Dialogue," dvb.no (Democratic Voice of Burma), 20 January 2015.

3 May Wong, "Myanmar Not Ready for Reduced Military Role in Parliament," Channel News Asia, 20 January 2015.

4 Zoltan Barany, The Soldier and the Changing State: Building Democratic Armies in Africa, Asia, Europe, and the Americas, Princeton: Princeton University Press, 2012, pp. 39-42.

5 Aurel Croissant and David Kuehn, "Patterns of Civilian Control of the Military in East Asia's New Democracies," Journal of East Asian Studies, Vol. 9, No. 2, May-August 2009, p. 191. 
6 Jinsok Jun, "South Korea: Consolidating Democratic Civilian Control," in Muthiah Alagappa (ed.), Coercion and Governance: The Declining Political Role of the Military in Asia, Stanford, CA: Stanford University Press, 2001, p. 123.

7 For a definitive assessment of Park's rule, see Byung-Kook Kim and Ezra F. Vogel (eds.), The Park Chung Hee Era: The Transformation of South Korea, Cambridge, MA: Harvard University Press, 2011, and particularly Joo-Hong Kim's chapter, “The Armed Forces,” pp. 168-199.

8 Jun, "South Korea: Consolidating Democratic Civilian Control," p. 128. 9 Ibid., p. 129.

10 Cited in Jongseok Woo, Security Challenges and Military Politics in East Asia: From State-Building to Post-Democratization, New York: Continuum, 2011, p. 71.

11 Jun, "South Korea: Consolidating Democratic Civilian Control," p. 129.

12 See John Roosa, Pretext for Mass Murder: The September 30th Movement and Suharto's Coup d'Etat in Indonesia, Madison, WI: University of Wisconsin Press, 2006.

13 Geoffrey Robinson, "Indonesia: On a New Course?," in Alagappa (ed.), Coercion and Governance, p. 227.

14 Herbert Feith, "Indonesia's Political Symbols and their Wielders," World Politics, Vol. 16, No. 1, October 1963, pp. 79-97

15 Harold Crouch, The Army and Politics in Indonesia, Ithaca, NY: Cornell University Press, 1988 [Rev. ed.]), pp. 273-303; and Woo, Security Challenges and Military Politics in East Asia, p. 131.

16 Angel Rabasa and John Haseman, The Military and Democracy in Indonesia: Challenges, Politics, and Power, Santa Monica, CA: RAND, 2002, p. 37.

17 Woo, Security Challenges and Military Politics in East Asia, p. 134.

18 Robinson, “Indonesia: On a New Course?," p. 228.

19 Joseph S. Bermudez, Jr., The Armed Forces of North Korea, London: I.

B. Tauris, 2001, pp. 13-16.

20 See for instance, James Lilley with Jeffrey Lilley, China Hands: Nine Decades of Adventure, Espionage, and Diplomacy in Asia, New York: Public Affairs, 2005, pp. 264-296.

21 Jun, "South Korea: Consolidating Democratic Civilian Control," p. 139.

22 Herbert H. Werlin, "Ghana and South Korea: Explaining Developmental Disparities," Journal of Asian and African Studies, Vol. 29, April 1994, pp. 205-225. 
23 Interviews with Indria Samego and Ikrar Nusa Bhakti, Indonesian Institute of Sciences, Jakarta, 16 and 17 December 2009.

24 Oren Barak and Gabriel Sheffer, "Continuous Existential Threats, CivilSecurity Relations, and Democracy," in Gabriel Sheffer and Oren Barak (eds.), Existential Threats and Civil Security Relations, Lanham, MD: Lexington Books, 2009, p. 131.

25 Jongryn Mo and Barry R. Weingast, Political Economy of Korea's Transition, 1961-2008, September 2009 (draft), p. 115.

26 See Hong-nack Kim, "The 1988 Parliamentary Election in South Korea," Asian Survey, Vol. 29, No. 5, May 1989, pp. 480-495.

27 Woo, Security Challenges and Military Politics in East Asia, p. 111.

28 Samuel P. Huntington, The Third Wave: Democratization in the Late Twentieth Century, Norman, OK: University of Oklahoma Press, 1991, pp. 231-251.

29 Victor Cha, "Security and Democracy in South Korean Development," in Samuel S. Kim (ed.), Korea's Democratization, New York: Cambridge University Press, 2003, p. 207.

30 Croissant and Kuehn, "Patterns of Civilian Control of the Military in East Asia's New Democracies," p. 193.

31 Woo, Security Challenges and Military Politics in East Asia, p. 112.

32 See Terence Roehrig, Prosecution of Former Military Leaders in Newly Democratic Nations, Jefferson, NC: McFarland \& Co., 2002, pp. 160-185. 33 Larry Diamond and Doh Chull Shin, "Introduction: Institutional Reforms and Democratic Consolidation in Korea," in Larry Diamond and Doh Chull Shin (eds.), Institutional Reform and Democratic Consolidation in Korea, Stanford, CA: Hoover Institution Press, 2000, p. 10.

34 Woo, Security Challenges and Military Politics in East Asia, pp. 113114.

35 Chaibong Hahm. "South Korea's Miraculous Democracy," Journal of Democracy, Vol. 19, No. 3, July 2008, p. 136.

36 Cha, "Security and Democracy in South Korean Development," p. 214.

37 Kim Dae-jung was elected on 18 December 1997 and the generals were released on 22 December 1997. Kim's official presidential term did not begin until 25 February 1998 but the decision, likely to have been influenced by the on-going financial crisis, was his and not the sitting president's. I am grateful to Jongseok Woo for this point.

38 Jun, "South Korea: Consolidating Democratic Civilian Control," p. 134. 
39 Croissant and Kuehn, "Patterns of Civilian Control of the Military in East Asia's New Democracies,” p. 193.

40 Interview with Kim Min-seok, Senior Expert Writer of the Joong Ang Ilbo Newspaper, Seoul, 4 December 2009.

41 Interview with Kim Choong-nam, Visiting Fellow, Sejong Institute, Seoul, 4 December 2009.

42 See Sunhyuk Kim, "Civic Mobilization for Democratic Reform," in Diamond and Shin (eds.), Institutional Reform and Democratic Consolidation in Korea, pp. 279-304.

43 See Jun Honna, Military Politics and Democratization in Indonesia, New York: RoutledgeCurzon, 2003, pp. 38-52.

44 Terence Lee, "The Armed Forces and Transitions from Authoritarian Rule: Explaining the Role of the Military in 1986 Philippines and 1998 Indonesia," Comparative Political Studies, Vol. 42, No. 5, May 2009, pp. 654-660.

45 See Ronald D. Palmer, "From Repression to Reform? Indonesian Politics and the Military, 1997-1999," in American Diplomacy, Winter 2000, <http:// www.unc.edu/depts/diplomat/AD_Issues/amdipl_15/palmer_reform1.html> 46 Croissant and Kuehn, "Patterns of Civilian Control of the Military in East Asia’s New Democracies,” p. 194.

47 Marcus Mietzner, Military Politics, Islam, and the State in Indonesia, Singapore: Institute of Southeast Asian Studies, 2009, p. 2.

48 Geoffrey Robinson, "If You Leave Us Here, We Will Die": How Genocide Was Stopped in East Timor, Princeton, NJ: Princeton University Press, 2009, pp. 139-161.

49 Rabasa and Haseman, The Military and Democracy in Indonesia, pp. 41-42.

50 See Mietzner, Military Politics, pp. 211-225.

51 Ibid., p. 227.

52 Interview with Marcus Mietzner, Jakarta, 15 December 2009; and e-mail communication from Evan Laksmana, 16 October 2011.

53 E-mail message from Juwono Sudarsono, 28 March 2010.

54 Interview with Frans Limahelu of Airlangga University, Austin, 18 October 2010.

55 See Lisa Misol, Unkept Promise: Failure To End Military Business Activity in Indonesia, New York: Human Rights Watch, 2010; and Harold Crouch, Political Reform in Indonesia after Soeharto, Singapore: Institute of Southeast Asian Studies, 2010, pp. 161-169. 
56 See the 2009 and 2010 issues of The Military Balance 2009, London: International Institute for Strategic Studies, p. 388 and 407; and p. 405 and 424 , respectively.

57 E-mail message from Juwono Sudarsono, 28 March 2010.

58 Interview with Jun Honna, Jakarta, 19 December 2009.

59 Interviews with Indria Samego, Kevin O'Rourke, Jun Honna, Marcus Mietzner and Ikrar Nusa Bhakti, Jakarta, 15-19 December 2009. See also, Susilo Bambang Yudhoyono, "The Democratic Instinct in the $21^{\text {st }}$ Century," Journal of Democracy, Vol. 21, No. 3, July 2010, pp. 5-10; and more generally, Crouch, Political Reform.

60 Interview with Mietzner.

${ }_{61}$ Michael C. Desch, Civilian Control of the Military: The Changing Security Environment, Baltimore, MD: Johns Hopkins University Press, 1999, pp. 111-112.

62 See for instance, Adam Przeworski, et al., Democracy and Development, New York: Cambridge University Press, 2000, especially pp. 78-141.

63 Huntington, The Third Wave, p. 252.

${ }^{64}$ See the 2013 report of Transparency International, <http://www. transparency.org/country\#MMR>

65 Maung Aung Myoe, "The Soldier and the State: The Tatmadaw and Political Liberalization in Myanmar since 2011," South East Asia Research, Vol. 22, June 2014, p. 233.

66 Author's interviews with democracy activists and opposition politicians in Rangoon, 1-5 October 2014.

67 See Marcus Mietzner, "How Jokowi Won and Democracy Survived," Journal of Democracy, Vol. 25, October 2014, pp. 111-125.

68 See for instance, Kyaw Yin Hlaing (ed.), Prisms on the Golden Pagoda: Perspectives on National Reconciliation in Myanmar, Singapore: National University of Singapore (NUS) Press, 2014. 